\title{
THE EXPERIENCE OF WORK-LIFE BALANCE FACED BY MOTHERS WITH PRESCHOOL CHILDREN
}

\author{
Inga CHISTRUGA-SINCHEVICI ${ }^{1}$, PhD in Sociology, \\ National Institute for Economic Research, Republic of Moldova \\ Natalia BARGAN2, \\ National Institute for Economic Research, Republic of Moldova
}

DOI: https://doi.org/10.36004/nier.es.2019.2-07

JEL Classification: J10, J13, J19

UDC: 614.3

\section{ABSTRACT}

The article presents the results of the sociological study "Parents between the need to work and family responsibilities" (in baze on 1047 questionnaires with mothers with preschool children and 20 in-depth sociological interviews), conducted by the Center for Demographic Research of NIER. The purpose of the study consisted in analyzing the particularities of reconciling the family life and the professional life of mothers with preschool children, in highlighting the difficulties they face in reintegrating into the labour market after child care leave and in determining the factors that contributes to facilitating the process of balancing family and professional life. The results of the study revealed that families face difficulties in establishing and maintaining a balance between many and sometimes contradictory demands offamily and professional life. The interviewed mothers highlighted a high level of motivation to be employed, but the defining reason for returning to the labor market is the need to earn money. Depending on the professional and family orientations, mothers with preschool children can be divided into three categories: mothers who want to combine the work with raising children (65\%), mothers who intend to make a career but do not forget about children (21.3\%) and mothers who prefer to be housewifes and take care of children (13.7\%). Although the support of the husband moderates the relationship between family and professional responsibilities, the results of the study have shown that there is a tendency for women to take full responsibility of the household and child care. The lack of quality care and education services for preschool children, the absence of flexible work programs but also the unequal distribution offamily responsibilities contribute to making the work-family life balance a predominant problem.

Keywords: life-work balance, work-family conflict, sociological study.

In articol sunt prezentate rezultatele studiului sociologic „Părinții între necesitatea de a munci și responsabilitățile familiale" (în baza la 1047 de chestionare cu mame cu copii de vârstă preșcolară și 20 de interviuri sociologice aprofundate), desfășurat de CCD al INCE. Scopul studiului a constat în analiza particularităților de reconciliere a vieții de familie și a vieții profesionale a mamelor cu copii de vârstă preșcolară, în evidențierea dificultăților cu care se confruntă la reintegrarea în câmpul muncii după aflarea în concediul de îngrijire a copilului și în determinarea factorilor ce contribuie la facilitarea procesului de echilibrare a vieții familiale și profesionale. Rezultatele studiului au relevat că familiile se confruntă cu dificultăți în stabilirea și menținerea unui echilibru între numeroasele și uneori contradictoriile solicitări ale vieții de familie și a celei profesionale. Mamele intervievate au evidențiat un nivel ridicat de motivație pentru a fi încadrate în câmpul muncii, însă motivul determinant pentru a reveni în câmpul muncii este necesitatea de a câstiga bani. În funcție de orientările profesionale și familiale, mamele cu copii de vârstă preșcolară pot fi divizate în trei categorii: mame care își doresc să combine serviciul cu creșterea copiilor (65\%), mame care intenționează să facă carieră, dar să nu uite nici de copii (21,3\%) și mame care preferă să fie casnică și să aibă grijă de copii $(13,7 \%)$. Deși sprijinul soțului moderează relația între responsabilitățile familiale și cele profesionale, rezultatele studiului au evidențiat că se păstrează tendința ca femeile să-și asume întreaga responsabilitate a gospodăriei și a îngrijirii copiilor. Lipsa serviciilor calitative de îngrijire și educație a copiilor

1 @ Inga CHISTRUGA-SÎNCHEVICI, $\bowtie$ i_sinchevici@yahoo.com

2 @ Natalia BARGAN, $₫$ nataly_bargan@gmail.com 
de vârstă preșcolară, absența programelor flexibile la locul de muncă, dar și continua distribuție inegală a responsabilităților familiale dintre soți determină faptul că îmbinarea rolurilor profesionale cu cele familiale rămâne o problemă predominantă.

Cuvinte-cheie: echilibrul viață-muncă, conflictul muncă-familie, studiul sociologic.

В статье представлены результаты социологического исследования «Родители между необходимостью работать и семейными обязанностями» (на основе 1047 анкет для матерей с детьми дошкольного возраста и 20 социологических глубинных интервью), проведенного Центром демографических исследований НИЭИ. Цель исследования состояла в том, чтобы проанализировать особенности совмещения семейных ролей и профессиональной деятельности матерей с детьми дошкольного возраста, выявить трудности, с которыми они сталкиваются при реинтеграции на рынке труда после отпуска по уходу за ребенком, и определить факторы, способствующие сбалансированности семейной и профессиональной жизни. Результаты исследования показали, что семьи сталкиваются с трудностями в установлении и поддержании определённого баланса между многочисленными, а порой и противоречивыми запросам семьи и требованиями профессиональной деятельности. Опрошенные матери продемонстрировали высокий уровень мотивации для включения в рынок труда, при этом определяющей причиной возвращения на рынок труда является необходимость зарабатывать деньги. В зависимости от профессиональной и семейной ориентации, матерей с детьми-дошкольниками можно разделить на три категории: матери, которые желают совмещать работу с воспитанием детей (65\%), матери, ориентированные на карьеру, не забывая приэтом о детях (21 3\%) и матери, предпочитающие быть домохозяйками и посвятить себя заботе о детях (13,7\%). Несмотря на то, что поддержка супруга способствует сочетанию трудовой деятельности с выполнением семейных обязанностей, результаты исследования показали, что женщины по-прежнему склонны нести полную ответственность за домашнее хозяйство и заботу о детях. Отсутствие качественных услуг по уходу и воспитанию детей дошкольного возраста, гибких программ на рабочих местах, а также продолжающееся неравное распределение семейных обязанностей между супругами способствуют тому, что баланс между работой и личной жизнью остается доминирующей проблемой.

Ключевые слова: баланс между работой и семейной жизнью, конфликт между работой и семьей, социологическое исследование.

INTRODUCTION. Family and work are two important focal points in adult's life and are interconnected. In today's society full of responsibilities and commitments, the relationship between work and family life has become a predominant problem, given that the balance between these aspects is one of the fundamental conditions for increasing the return on human capital.

The deep interest in the relationship between professional and family lifes is due to sociodemographic factors - increase in the number of couples in which both partners are employed, in the number of single-parent families, but also due to the emphasis on the importance of professional identity for women. In addition, the fact that the age of formation of families is constantly increasing contributes to the emergence of the phenomenon of the "intermediate" or "sandwich" generation, consisting of those who have to take care of an elderly relative while raising small children, studies show that women are more likely than men to experience this situation [20, ST-AMOUR N. ș.a., 2007].

Difficulties in maintaining a balance between professional and family lifes are also determined by the reduced child care and education facilities, the system of child care and education not beeing sufficiently developed; by the rigidity of work schedules that do not allow to achieve a balance between professional and personal life and the continuous unequal distribution of family tasks between husband and wife, family responsibilities interfering with career development.

The tasks of combining professional and family roles are today the objectives of state social policy. The Republic of Moldova has a developed legislative framework and actively participates in international treaties that prohibit discrimination in employment. In the National Strategic Program on Demographic Security of the Republic of Moldova (2011-2025) it is specified that in order to develop measures to solve family problems, it is proposed to promote the father's broader involvement in raising children by granting paid leave of paternity and leave for raising the child with special provisions for fathers; establishing a flexible work program to facilitate the process of raising children; ensuring equal payment / remuneration for women and men. 
Also, several changes were made to the legal framework. According to the amendments to the Law on temporary disability allowances and other social security benefits from July 1, 2019, parents who receive child care allowances but decide to work will receive both the allowance and salary. The child care leave has been reformed by increasing the child care allowance commensurate to the reduction of the period of care leave. Other changes are related to reducing unpaid care leave from 6 years to 4 years and completing the Labor Code with art. $124^{1}$ Parental leave.

THE THEORETICAL FRAMEWORK OF THE STUDY. The key concepts used in the present scientific paper are: work-family life balance, work-family conflict and family-work conflict.

The syntagm "work/life balance" was proposed in 1985, although its use in everyday language has been sporadic for several years. The balance between these two components means allocating an equal interval of time to both segments of life, avoiding the disadvantage of one of them. This balance does not come by itself and is the result of a good organization and discipline, varying according to individual, family, organizational and societal characteristics. The conceptualization of work-family balance as a conflict is related to the deficit hypothesis, according to which individuals possess a certain amount of time and energy that must be distributed between different roles they play.

Researchers Greenhaus J. and Beutell N. [12, 1985] had an important role in conceptualizing the term of conflict between work and family, establishing that conflict can have three forms: based on time, tension and behavior. Time-based conflict arises when the pressures in one area affect the fulfillment of the requirements associated with the other one, the employees do not have enough time to successfully or comfortably complete all the tasks associated with their work and family. Time-based conflicts arise when the demands imposed by different roles make time management difficult. Moreover, concerns about one role may affect the readiness to perform tasks related to another role, even if the person is physically present. Tension-based conflict results when stress generated during the performance of a role affects how a person meets the requirements of other roles. Behavior-based conflict refers to the phenomenon whereby a behavior specific to one role is incompatible with the behavior required of another role. Certain characteristics that are appreciated in the world of work, such as objectivity and aggressiveness, may be incompatible with family needs and expectations. There is a need to adjust the behaviors to the context in which the person is.

Some researchers like Sulea C., Virga D., Galben N. have pointed out that women experience more work-family conflict based on behavior and family-work conflict based on tension. That is, women cannot take on the successful behavioral strategies that they adopt at work to solve family problems, and the tensions in their personal lives tend to generate conflicting states at work. Men experience, to a greater extent, work-family conflict based on time. That is, they spend too much time at work and have no time resources for family activities [23, SULEA C., VÎRGĂ D., GALBEN N., 2010].

In the specialized literature two directions of the conflict between work and family are distinguished: the work-family conflict and the family-work conflict. Work-family conflict occurs when work-related activities intersect with household responsibilities or when work-related stress has negative effects on family behaviors. The conflict between family and work arises when family responsibilities impede work activities or when family stress has negative effects on work performance. Although closely related, they are conceptually and empirically distinct constructs. conflict:

The analysis of literature [1, AHMAD A., 2008] in the field allowed us to identify several sources of

1. from the workplace: the ambiguity of roles in the workplace; overcharging; organizational culture; frequent job related trips; style of time management practiced in the organization; type of job position; job flexibility.

2. from the perspective of personal beliefs and aspirations: the lifestyle; perfection in work; emotional health problems; values of the role of life.

3. from the family: needs regarding the assurance of financial or material resources; maintaining and sustaining interpersonal relationships; involvement in raising and educating children; health problems of a family member; number of children; life cycle stage; child care arrangements.

An important researched aspect concerns the specific factors related to the evolution of technologies with implications in generating conflicts between work and family. In the contemporary professional life, new technologies allow the accomplishment of professional tasks not only in different locations, but also 
outside the official working time. The pressure to meet increasingly tight deadlines, as well as the need to be permanently available to clients, has led to the extension of the professional life towards the family [25, ZAHARIA V., GAVRILOAIEI S., 2015]. A study from the Russian Federation also highlighted this issue by pointing out that mobile devices allow employees to respond quickly, constantly accessing and sharing information, contributing to increased employee productivity and encouraging cooperation between them. But the continuous participation in the professional life, in the long term, reduces the productivity because workers do not have time to rest and to recover and the professional exhaustion increases. Thus appeared the "right to disconnect", giving the person the opportunity to "disconnect" from the workplace, from the use of electronic communications, such as emails and messages after the end of the work day [22, SON KH. I., CHERNOVA ZH., 2018].

Data from studies also show that, in general, young people are those who face difficulties in balancing work and family. Therefore, young people represent the group of employees who most likely seems to be affected by the work-family conflict. Many of them being newly married and early in their professional careers have not yet developed the skills to effectively balance the tasks associated with these roles - the parental/marital and the professional one. This fact indicates the need for more organizational support in this regard [18, PLATON C., 2016].

Researchers believe that the conflict between work and family has become an important area of research for organizations because of the negative effect these conflicts have on the behavior of employees at work and at home [11, GRANDEY A., CROPANZANO R., 1999; 20, ST-AMOUR N. ș.a., 2007; 24, YOUNGCOURT S., HUFFMAN A., 2005]. The consequences of the conflict between work and family life are complex, reflecting on:

- the employee: high level of stress, physical and emotional health problems (depression, anxiety), risky behaviors (alcohol consumption), increased marital stress, low career satisfaction, tension, irritability, frustration, vulnerability, insecurity and poor work performance.

- the employee's children: behavioral and emotional problems.

- at the organizational level: low fidelity to the company, increased interest in changing the job as a "method" for resolving conflicts, increasing staff turnover, absenteeism and high costs generated by health problems of employees/medical leave, low productivity [2, 2019].

The problems of reconciling family and professional life contribute to the emergence of the "delayed maternity" phenomenon, meaning that more women employed on the labor market are less likely to become mothers at a younger age. Conciliation problems are factors that prevent couples from having many children, thus contributing to lower birth rates. A low birth rate has a negative influence on economic growth as well as on the stability of social protection systems. International comparisons indicate a positive correlation between an efficient labor market presence and higher fertility (for example in France and Sweden) [8, 2004].

Recent studies in the field have also focused on studying the wage penalty for motherhood due to the difficulties of reconciling family and professional life. It has been established that the motherhood penalty increases with the number of children, especially young children [10, DAVIESA R., GAE"LLE P., 2005; 17, PILAR CASAL M., BARHAM B., 2013]. This penalty arises because with the birth of children women interrupt their work experience. Another reason is that maternity and household tasks can leave women exhausted while working, resulting in decreased productivity. Some women might give up work with higher wages in favor of family-friendly jobs that allow them to work fewer hours and spend more time at home. Some researchers - Anderson, Binder, and Krause (2002) have established that the motherhood penalty for lower-skilled workers is minimal, while mothers with higher education have a $15 \%$ wage penalty [17, PILAR CASAL M., BARHAM B., 2013]. Other studies have also shown that mothers with higher education receive a "fine" of 1.5 times higher than those without higher education. The difference in remuneration for mothers with higher education appears after the birth of the first child, while among the women without education, starting from the second birth [4, BIRYUKOVA S., MAKARENTSEVA A., 2017].

The theoretical-methodological basis consists of: conflict theory that emphasizes the dynamic nature of family life and the role of external factors (economy, politics, social structure); development theory, according to which the family goes through several stages of the family life cycle and the gender theory, according to which the conceptions and ideas regarding the family life of men are different from those of women, etc.

In the Republic of Moldova, this subject remains insufficiently exploited. In the 2015-2018 period the project "Interferences between professional work and private life. Intercultural aspects, local experiences 
and intervention strategies" was carried out within the Faculty of Psychology of the Moldova State University. Within this project, various aspects related to the relationship between the professional and family life of employees in the Republic of Moldova were investigated, but from a psychological perspective.

METHODOLOGY OF THE STUDY. The article is elaborated on the basis of the qualitative sociological study "Parents between the need to work and family responsibilities" carried out during August - October 2018 by the Center for Demographic Research, NIER, during which 20 sociological interviews were conducted with mothers with children of preschool age (up to 6 years). Also, the article is based on the data of the quantitative study "Parents between the need to work and family responsibilities" (1047 questionnaires with mothers with preschool children), carried out during February-March 2019. It was opted to conduct the study only in Chisinau for several reasons: persistence of demographic problems: increase in the age of women at childbirth; intensification of the phenomenon of postponement of childbirth; lack of quality preschool education services, especially for young children; in most families both partners are employed; increase in the number of single parent families; concentration of young population, young families, families with young children; extensive employment opportunities; high level of education of the female population.

The purpose of the study consisted in analyzing the particularities of reconciling the family life and the professional life of mothers with preschool children, in highlighting the difficulties they face in reintegrating into the labour market after child care leave and in determining the factors that contributes to facilitating the process of balancing family and professional life.

The general hypothesis of the study refers to the fact that the relationship between the professional and family life of mothers with preschool children is conditioned by the accessibility of the preschool education services, economic and psychosocial resources of the family, individual resources (education) and the flexibility of work programs.

Characteristics of the sample. Out of the total sample, $30 \%$ of mothers had children up to 3 years old and the rest between 3 and 7 years. Depending on the level of training 9.1\% of the respondents had gymnasium and secondary school education, 17.9\% post-secondary education (college, professional school), 5.6\% lyceum and 67.3\% - higher education. Depending on the occupational status - 59.7\% were employees; private entrepreneur - $3.6 \%$, self-employed $6.6 \%$, unemployed $11.2 \%, 1.2 \%$ - working abroad and $17.9 \%$ were on maternity leave or child care leave. Out of the total number of those employed, $45.3 \%$ worked in the public sector, $50.2 \%$ in the private sector and the rest in other sectors (4.5\%).

RESEARCH RESULTS. The interviewed mothers showed a high level of motivation to be employed. $45.2 \%$ wanted/want to start working again before the child is 3 years old. But the main reason for returning to the labor market is the need to earn money (Fig. 1). "If there would be someone to support us, I would stay up to 3 years at home with the child. I am sorry for him, when I have to go to work, he comes to me and does not want to leave me."

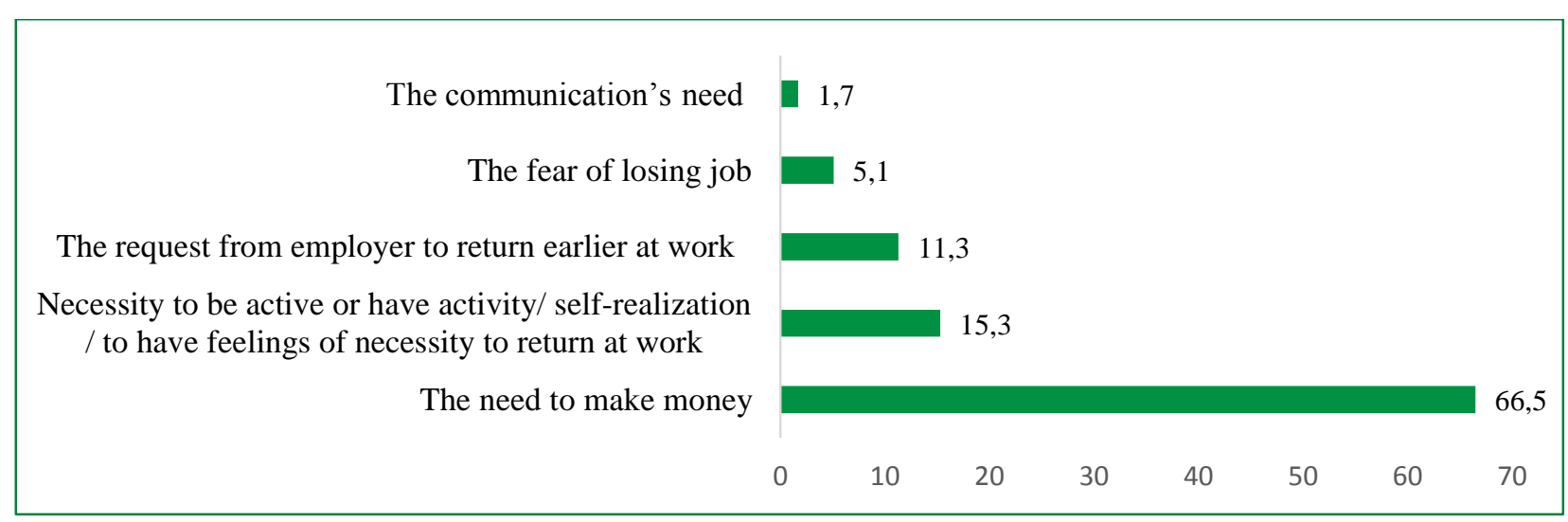

Figure 1. Reasons for early return to work after child care leave (in \%)

Source: The sociological study "Parents between the need to work and family responsibilities". 
The study allowed us to elaborate the typology of mothers with preschool children, according to their professional and family orientations, and their characterization:

Mothers who wish to combine the job with the raising of children (65\%) - most of them had the status of employees; work in the public sector; the activity stage is reduced; most of them return to work after child care leave. They appreciate that harmoniously combine work with family life. It was pointed out that most of them consider that they like to work, but do not want a too demanding professional activity. For mothers in this category, work is just a source of income for life.

Mothers who intend to make a career but do not forget about children (21.3\%) - usually have a higher education level; hold management positions; most of them are active in the private sector of the economy; the duration of child care leave is short. They appeal to particular child care services. They admit that are more dedicated to the field of activity than family life. They benefit from the necessary support/baking of the husband when returning to work. They are very satisfied with the work they are hired for.

Mothers who intend to be housewifes and take care of children (13.7\%) - most of them have gymnasium, secondary education; have three and more children; most of them occupy execution functions; predominantly work in the fields of manufacturing and trade; a significant number of them work up to 6 hours a day. More than half of them changed their jobs after child care leave. The husband, in most cases, is the main earner of the family and he is also the one who most often makes the household decisions. They admit that they are more dedicated to children and more satisfied with their parenting, to the detriment of their careers.

Totally $35.4 \%$ of those who returned to work changed their jobs, mainly those who worked in the private sector of the economy changed their jobs. This aspect highlights the persistence of increased insecurity in private companies. Thus, some women intentionally choose / give preference to the public sector to benefit from maternity leave, child care and medical leave. "I know that the rights to motherhood are not really respected in private companies, that is why I decided to work in public sector, where the rights of mothers with children are respected. My colleagues made it clear to me that if I want to have children in the future, then it would be better to leave from here. I have found that you cannot be a mother in private company in our country". "I better work in a state institution with a lower salary, but to be respected, to feel as human, and for individuals with more money being considered a money-making machine, which, if used, can be thrown away".

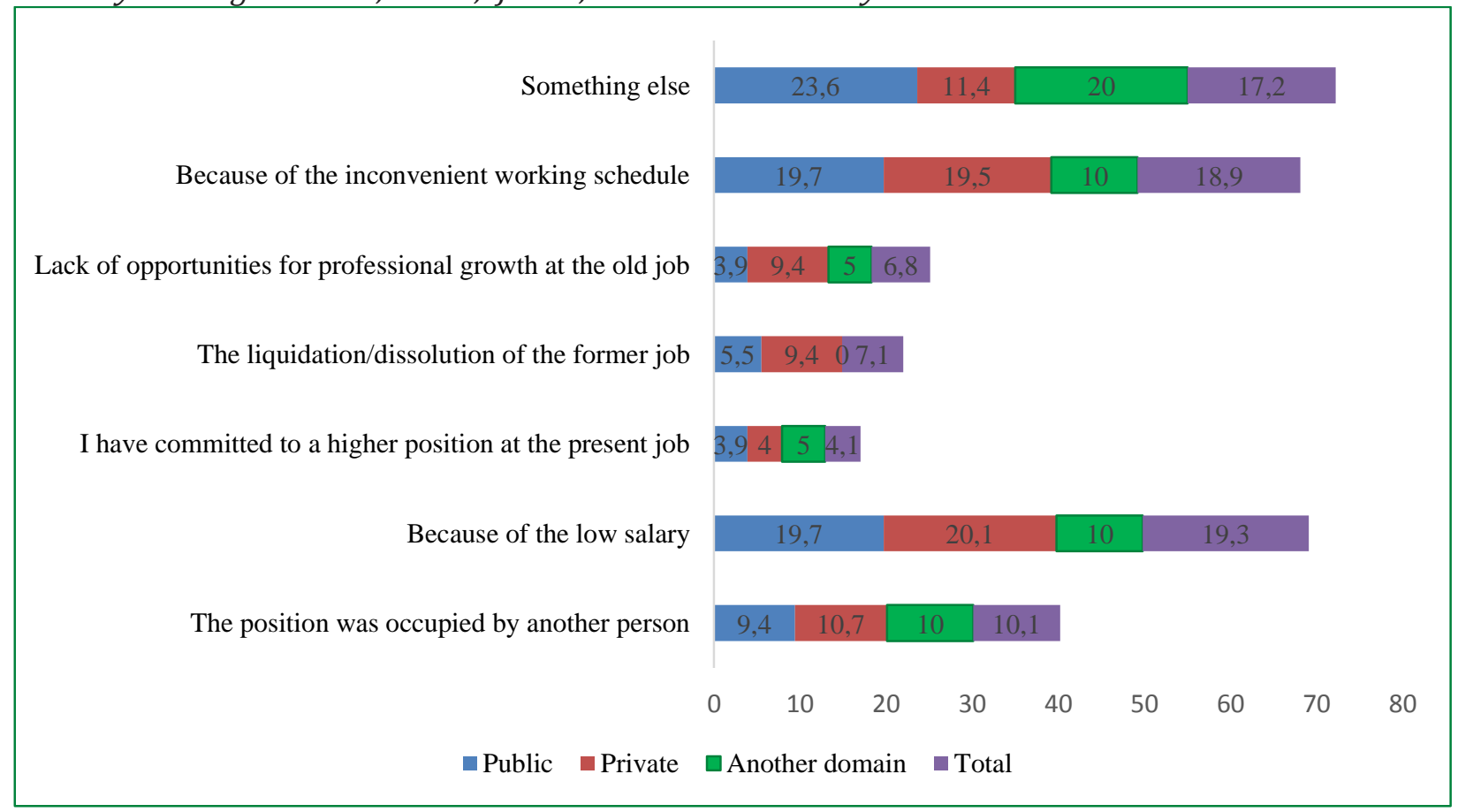

Figure 2. Causes of job change (in \%)

Source: The sociological study "Parents between the need to work and family responsibilities"

No. 2 / 2019 
The data in Fig. 2 emphasizes some problems that are attested in the private environment, such as occupying the position previously held by other persons contrary to the legal framework that ensures the retention of the job upon the return from the child care leave and the lack of prospects for professional growth. In some international studies [5, BUELENS M., BROECK H., 2007] it was also found that public sector workers face fewer conflicts between personal and professional life than private sector workers and also have a higher level of satisfaction with family life and more free time.

The results of the study also revealed the problem of the limited possibilities of part-time job for mothers. Thus, in some situations mothers wanted to integrate into the labour market from an earlier age of the child, opting for a part-time work, but in the absence of this possibility, they have to work full time or not at all. "Initially, I wanted to work part-time, that is 4 hours, but I was not allowed. I was told either full time, or not at all".

If we interpret the decision to work part-time as a voluntary one, then the increased possibility of benefiting from such a work arrangement can be viewed as an opportunity for women to earn income from an activity that can be combined with the fulfillment of the other responsibilities [16, LEOVARDIS C., NICOLAESCU C., 2011]. In some situations, part-time work helps women to balance their family and professional lives. In some studies it has been established that women who work part time report a higher level of happiness at home and a greater satisfaction with their children than women who work full time [14, HIGGINS C. et al., 2000].

To evaluate the indicators of family-work and work-family conflict, a literature review was performed using the scales proposed by Turkish researchers Gürcü Erdamar, Hüsne Demirel, which were translated and adapted. Each question was answered as Never (1), Rare (2), Occasional (3), Often (4) and Always (5). Given that the family is more important than the work, the value of the family-work conflict is higher than that of the work-family conflict, constituing 25.4 and 21.92 respectively.

Table 1

The value of work-family conflict

\begin{tabular}{|l|c|c|}
\hline $\begin{array}{l}\text { 1. Because I have many tasks and responsibilities at work, I } \\
\text { cannot spend enough time with my family }\end{array}$ & 2,66 & 1,086 \\
\hline $\begin{array}{l}\text { 2. Physical and mental fatigue at work makes it difficult to fulfill } \\
\text { my responsibilities at home }\end{array}$ & 2,72 & 1,043 \\
\hline $\begin{array}{l}\text { 3. Workplace fatigue decreases my patience with family } \\
\text { members }\end{array}$ & 2,38 & 1,073 \\
\hline $\begin{array}{l}\text { 4. Work assignments make me feel tired while fulfilling my } \\
\text { responsibilities at home }\end{array}$ & 2,66 & 1,052 \\
\hline $\begin{array}{l}\text { 5. I can't use the time for homework because of my service. I } \\
\text { always postpone doing the housework }\end{array}$ & 2,32 & 1,087 \\
\hline $\begin{array}{l}\text { 6. My professional life diminishes my efforts necessary to fulfill } \\
\text { my household responsibilities }\end{array}$ & 2,29 & 1,083 \\
\hline $\begin{array}{l}\text { 7. I continue to think at home about a problem I faced in the } \\
\text { workplace }\end{array}$ & 2,63 & 1,119 \\
\hline 8. A problem at work makes me stressed and nervous at home & 2,44 & 1,067 \\
\hline $\begin{array}{l}\text { 9. My duties and responsibilities in the workplace are a priority } \\
\text { of my family life }\end{array}$ & 1,82 & 1,158 \\
\hline Total & 21,92 & 9,76 \\
\hline
\end{tabular}

Source: The sociological study "Parents between the need to work and family responsibilities"

According to the study, mothers with higher level of education experienced a greater conflict between work and family than those without higher education. This can be explained by the fact that people with higher education work in jobs characterized by greater responsibility. 
The value of the family-work conflict

\begin{tabular}{|l|c|c|}
\hline $\begin{array}{l}\text { 1. My responsibilities at home diminish the time and effort I should } \\
\text { devote to professional activity }\end{array}$ & 2,01 & 0,970 \\
\hline $\begin{array}{l}\text { 2. Because I have too many responsibilities at home, I do not put } \\
\text { the work at the forefront }\end{array}$ & 2,22 & 1,075 \\
\hline $\begin{array}{l}\text { 3. My responsibilities at home create difficulties in my professional } \\
\text { life }\end{array}$ & 1,83 & 0,952 \\
\hline $\begin{array}{l}\text { 4. Family troubles and problems negatively affect my professional } \\
\text { life }\end{array}$ & 1,81 & 0,960 \\
\hline 5. A family problem makes me feel stressed and nervous at work & 2,07 & 1,006 \\
\hline 6. At work I continue to think of a problem I faced at home & 2,42 & 1,019 \\
\hline $\begin{array}{l}\text { 7. Certain situations I encounter at home (guests, illness, a child } \\
\text { problem) make my work difficult }\end{array}$ & 2,43 & 0,994 \\
\hline $\begin{array}{l}\text { 8. Domestic tasks reduce the time I have for sleep, which is } \\
\text { essential for my service }\end{array}$ & 2,55 & 1,140 \\
\hline 9. Because of my family responsibilities, I always go to work tired & 2,22 & 1,027 \\
\hline $\begin{array}{l}\text { 10. Due to my responsibilities in the family, I cannot participate in } \\
\text { certain activities related to my professional activity (meeting, } \\
\text { dinner, etc.) }\end{array}$ & 2,28 & 1,128 \\
\hline $\begin{array}{l}\text { 11. My family duties and responsibilities are above my } \\
\text { professional life. }\end{array}$ & 3,56 & 1,395 \\
\hline Total & 25,4 & 11,66 \\
\hline
\end{tabular}

Source: The sociological study "Parents between the need to work and family responsibilities".

The data in Fig. 3 shows that the value of conflict for both work-family and family-work components is higher for mothers who have children up to 3 years old than for mothers who have children from 3 to 7 years. Researcher Ahmad A. emphasized that work-family conflicts need to be investigated according to the stage of the family life cycle. Young children are dependent on parents, especially mothers, which explains this direct correlation [1, AHMAD A., 2008].

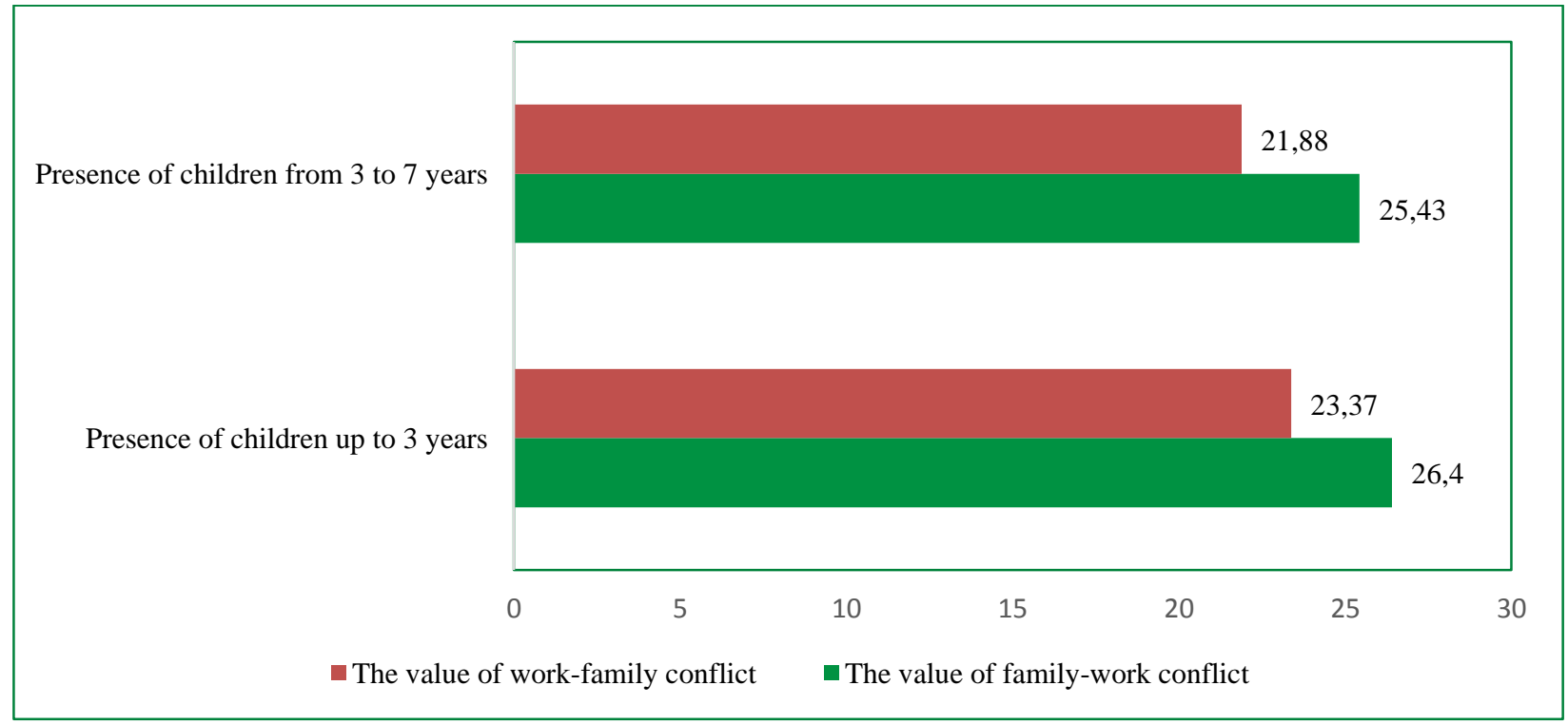

Figure 3. The value of family-work and work-family conflict depending on the age of children (in \%)

Source: The sociological study "Parents between the need to work and family responsibilities".

No. 2 / 2019 
The results of the author's study showed that women with young children from Chisinau municipality face the reluctance and inability of employers to offer them any conditions that would allow them to harmoniously combine family and professional life. Companies in the Republic of Moldova are still reluctant to create flexible work schedules. This is argued by the fact that $46.6 \%$ of interviewed mothers mentioned that they face the need to have a flexible working schedule (Fig. 4). The short and medium term flexibility is expected to solve the problems of episodic childhood diseases of children. "I feel very much the need to have a more flexible program, so that I can pay more attention and time to the care of the children. At my workplace I cannot benefit from such luxury in any form. We have very strict requirements. Probably, I should have another job." However, the flexibility of the work program is decisive in choosing a specific job, because the employees do not neglect their responsibilities towards the family.

Impossibility to have a needed flexible work schedule

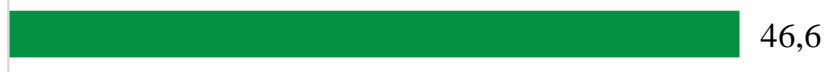

The necessity to stay over working hours program

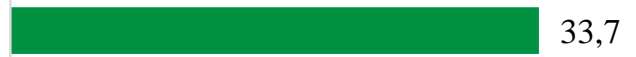

The employer's negative attitude regarding medical leave

Lack of opportunity to take vacation leave when needed / when you want

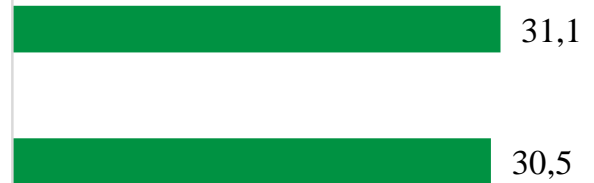

Impossibility to mack changes of working hours in unpredictable situations

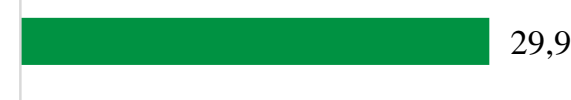

The technological working process at the job place cannot be interrupted

Lack of possibility to go in business / job trips

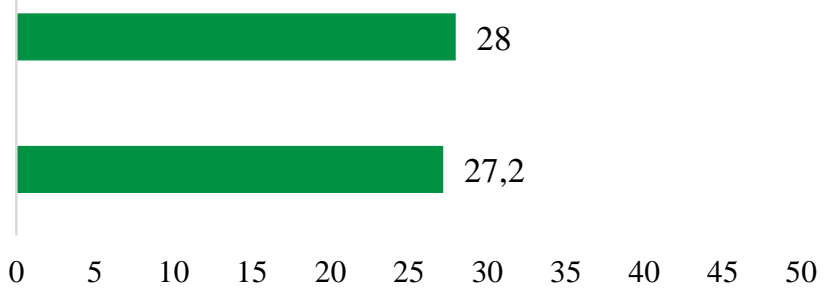

Figure 4. Situations faced by mothers in the workplace, (the total of answers always and often in \%)

Source: The sociological study "Parents between the need to work and family responsibilities".

One third of the respondents acknowledged that they were in the situation when they stayed late at work overtime. "There are certain periods, specific to the type of activity, due to which the work program lasts up to 10-12 hours daily." "I stay overtime sometimes because of the lack of staff and large workload."

$31.1 \%$ of surveyed mothers emphasized that they encountered at the workplace the employer's dissatisfaction with taking medical leave to care for their sick child. Concrete cases in which mothers face the impossibility of being on medical leave were presented within conducted interviews. "I could not take any medical leave, from my colleagues I understood that if I would take at least one I would not work anymore." The total number of days, during the last 3 months, in which the respondents were absent from work, being on child care leave constituted 4099. 279 mothers stated that they were on medical leave, on average, a mother was on medical leave for 14 days. $49.5 \%$ of the respondents mentioned that it happened in the last 3 months them to work, although they had to take medical leave due to the child's health. 
Another issue related to the provision of medical leave refers to the impossibility of mothers who work part-time to benefit in addition to the salary and the monthly allowance for child care to take this leave in case the child becomes ill. "I cannot take medical leave because I am on child care leave and also I work 7 hours. When the child becomes ill, the husband takes his medical leave so that we do not lose money."

The data from the qualitative study also highlighted the existence of impediments at work that make it difficult to create a harmonious balance between work and family:

The need to complete various registers, reports for the purpose of providing permission slip. "Right now I am going with the girl to do investigations. It is necessary to write in a special register and to ask permission from 3 heads every time. This is very unpleasant, it is the health of the child, I do not go to clinics just for a walk."

Restrictions of the legal framework. "If an accident occurs during working hours, even if it is not inside the company, it is considered an accident at work. We are responsible for the life and safety of our employees".

Compliance with hygiene and safety rules in the situation work from home. "We have to make sure the room is bright, the cables are ok. But we will not go and check in his house."

Insufficient legal regulation of the issues related to offering flexible programs and work from home. "The law does not allow, but also does not prohibit work from home."

These problems reveal that many organizations have very limited provisions regarding the reconciliation of family and professional life. Thus, there is still a long way to go for them to be considered "family friendly".

Child care services represent a determining factor in ensuring the balance between work and child care. Most children in preschool institutions are between 3 to 6 years old, this denotes the lack of the segment of services for the care of children under the age of 3 years. Only $56.1 \%$ of the respondents were confident that they can leave the small child in the care of someone, knowing that everything will be fine when they return from work.

The educational system in Chisinau is insufficiently developed to comprise all children of preschool age. Due to the under-financing of the preschool institutions, absolutely all the respondents acknowledged that within the institution attended by the child/children, financial sources are collected for repairs, endowment with furniture, household items, additional payment of personnel and other necessities. Due to the lack of confidence in the quality of preschool educational services, due to the shortage of well-trained specialists some parents access private educational institutions, but due to the high price, their number is limited.

The activity of babysitters/nannies is not sufficiently regulated in the Republic of Moldova, this is currently possible under the patent holder regime, and the obtaining of patent does not require compliance with a certain set of conditions that must be verified by the state when giving the patent (criminal record, studies, medical certificate, etc.).

$36.9 \%$ of interviewed mothers mentioned that a preschool child suffer if his mother works. The success of the mother in the implementation of the career has a socializing significance for the children, teaching them to treat a person with freedom of choice. On the other hand, lack of maternal attention can affect their personal development, complicating the relationship with the mother [3, BEREZOVSKAYA T., 2012]. Other studies have also shown that longer periods of maternity leave are generally associated with better health outcomes for mother and child [21, SKINNER N. CHAPMAN J., 2013]. In other research it is emphasized that the work activity of the mother has a different effect on the children: if the work brings satisfaction and the feeling of self-realization for the mother, the children not only do not suffer, but receive certain benefits (communication becomes more significant). On the contrary, if for mothers the work is nothing more than a means of earning for living, then being involved in different responsibilities, roles, overload, her dissatisfaction can create feelings of guilt, tension [9, KONOVALOVA A.M., 2011].

Progress towards a more equal distribution of child care and household tasks between women and men is slow, and the division of household and child care activities between men and women is very limited. "He says so, I'm a man, I make money. You are a mother, you stay at home and take care of children." "I do everything related to the house and kids, but the father makes money." At $70.6 \%$ of 
respondents the husband agreed with the idea of returning to work, at $65 \%$ the husband gave her the necessary help to return to work, and at $12.5 \%$ of respondents the husband considers that the work negatively affects the fulfillment of family responsibilities. This denotes the predominance of traditional values, according to which women should give priority to family responsibilities, while men should play the role of breadwinner in the family.

The data in Fig. 5 reveals that the daily division of family activities remains asymmetrical and very traditional, women being still responsible mainly for child care and household tasks. This is due to the cultural environment in which the family roles and obligations are defined. The tendency persist for women to take full responsibility of the household and the child, even working full time. But the husband's support moderates the relationship between work stress and the work-family conflict, so it is still necessary to promote the "responsible fatherhood" model [7, CHERNOVA ZH., 2012], that is, increasing the participation of men in the care and education of children.

Play or spend time with children, have fun together

Talk with children about their problems

Get kids out of kindergarten

Take kids to the kindergarten

Prepare the children for bedtime or watch for them.

Read the evening story to the children

Wash dishes

Clean the house

Wash toddlers

Feed young children

Take the kids to the doctor

Stay at home with sick children
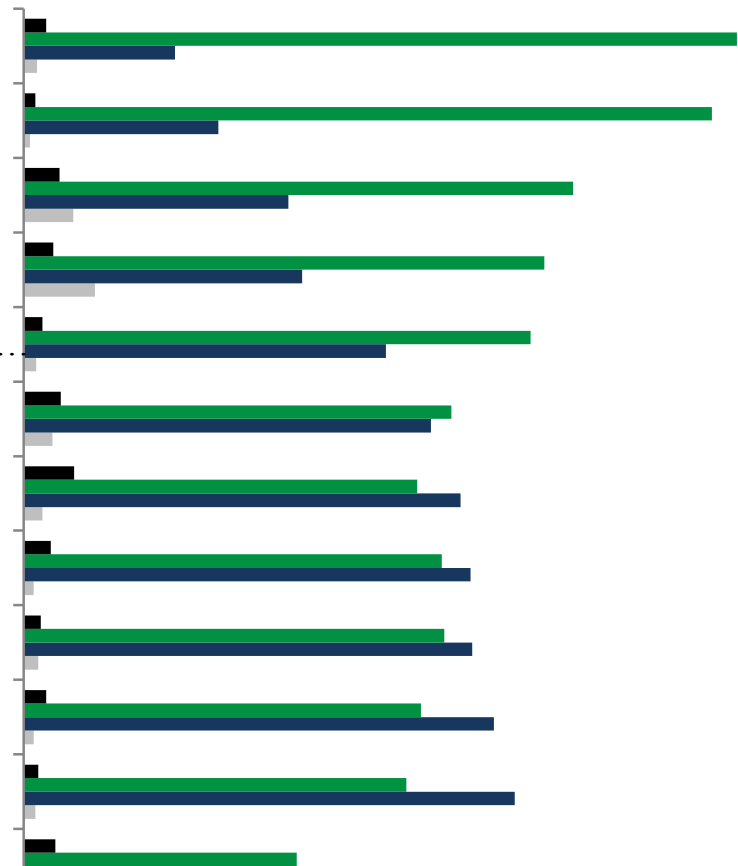

\section{Prepare food \\ Clean/wash clothes}

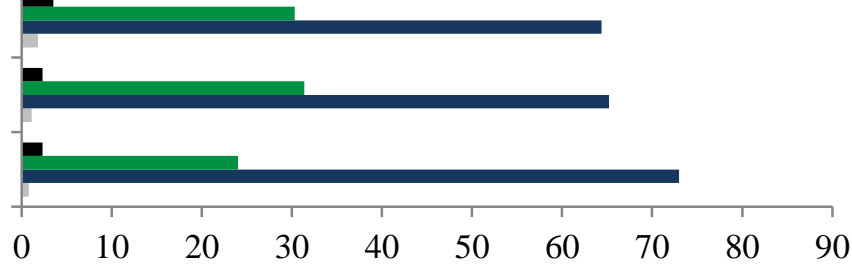

Somebody else $\quad$ Mom and Dad equally $\quad$ Always mother $\quad$ Always farther

Figure 5. Parents involvement in the education and care of children (in \%)

Source: The sociological study "Parents between the need to work and family responsibilities".

\section{CONCLUSIONS}

Finding a work-personal life balance for mothers is an essential issue for the well-being of children, as both poverty and lack of attention can harm the development of the child. A good balance reduces parental stress and therefore benefits both the parent-child relationship and the parentparent relationship.

Lack of nursery and early education services, inadequate conditions in some kindergartens make it difficult to combine professional and parental roles for mothers with young children. Some women choose to leave the labor market for a longer period of time than to face working conditions that do not allow them to balance their professional and family responsibilities. Thus, mothers are in 
a position to pay even a "fine" for motherhood.

The rigidity of the legal framework determines the impossibility of the employers to offer them some conditions that would allow them to harmoniously combine the family life with the professional one - flexible work programs, work from home, etc.

Mothers involved in the labor market face a conflict of role and in the absence of some facilities, the strategy for combining family life and work is to reduce fertility or delay it, meaning more women in the labor market are less likely to become mothers at a younger age.

\section{REFERENCES}

1. AHMAD A. Job, Family and Individual Factors as Predictors of Work-Family Conflict. 2008. [Accesat 21.11.2019]. Disponibil:https://www.researchgate.net/publication/260294449

_Job_Family_and_Individual_Factors_as_Predictors_of_Work-Family_Conflict

2. ASSOCIATION CANADIENNE POUR LA SANTÉ MENTALE. Le manque de conciliation vie personnelle - travail, facteur de risque. [Accesat 23.09.2019]. Disponibil:

https://www.mouvementsmq.ca/sites/default/files/3-manque.pdf

3. BEREZOVSKAÂ, T.P. Social'no-psihologičeskie osobennosti ženŝin, uspešnyh v kar'ere. V: Sem'â i ženŝina v sovremennom mire: social'nye i kul'turnye aspekty: meždunarodnaâ naučnaâ konferenciâ, 2 fevralâ 2012. Minsk, 2012, ss. 414-417. ISBN 978-985-552-151-9.

4. BIRÛKOVA, S., MAKARENCEVA, A. Ocenki «štrafa za materinstvo» v Rossii. V: Naselenie i èkonomika. 2017, Tom 1, № 1, ss. 50-70. ISSN 2658-3798.

5. BUELENS, M., BROECK, H. An Analysis of Differences in Work Motivation Between Public and Private Sector Organizations. In: Public Administration Review. 2007, vol. 67 (1), january, pp. 65-74. ISSN 1540-6210.

6. KALABIHINA, I., BIRÛKOVA, S. i dr. Sodejstvie professional'noj zanâtosti ženŝin s malen'kimi det'mi. Moskva, 2016. [Accesat 23.09.2019]. Disponibil: https://publications.hse.ru/en/books/198213850

7. ČERNOVA, Ž.V. Balans sem'i i raboty: politika i individual'nye strategii materej. In: Žurnal issledovanij social'noj politiki. 2012, Tom 10, № 3. [Accesat 23.10.2019]. Disponibil: https://cyberleninka.ru/article/n/balans-semi-i-raboty-politika-i-individualnye-strategii-materey

8. Conciliation entre Vie professionnelle et Vie familiale: rapport de synthèse de l'évaluation par les pairs. Berlin, 2004, 13-14 décembre. 35 p.

9. KONOVALOVA, A.M. Žiznennye strategii ženŝin: vybor i ego posledstviâ. V: Psihologiâ zrelosti i stareniâ, 2011, № 3, ss. 34-49. ISSN 0236-4999.

10. DAVIESA, R., GAE"LLE, P. The family gap in pay in Europe: A cross-country study. In: Labour Economics. 2005, vol. 12, pp. 469-486. ISSN 0927-5371.

11. GRANDEY, A., CROPANZANO, R. The Conservation of Resources Model Applied to Work-Family Conflict and Strain. In: Journal of Vocational Behavior. 1999, vol. 54 (2), april, pp. 350-370. ISSN 00018791.

12. GREENHAUS, J., BEUTELL, N. Sources of conflict between work and family roles. In: The Academy of Management Review. 1985, vol. 10, no. 1, pp. 76-88. [Accesat 01.11.2019]. Disponibil:

https://www.researchgate.net/publication/287011938_Sources_of_conflict_between_work_and_fa mily_roles_Academy_of_Management_Review_Vol

13. GREENHAUS, J.H., KAREN, M.C., SHAW, J.D. The relation between work - family balance and quality of life. In: Journal of Vocational Behavior. 2003, vol. 63, no. 3, december, pp. 510-531. ISSN 0001-8791.

14. HIGGINS, C., DUXBURY, L., JOHNSON, K. Part-time work for women: does it really help balance work and family? 2000. [Accesat 23.09.2019]. Disponibil:

https://www.researchgate.net/publication/255569927_PartTime_Work_for_Women_Does_It_Reall y_Help_Balance_Work_and_Family

15. ISUPOVA, O. Materinskaâ kar'era: deti i trudovye strategii. V: Sociologičeskie issledovaniâ. 2015, № 10, ss. 185-194. ISSN 0132-1625.

16. LEOVARDIS C., NICOLAESCU C. Raportul viață profesională-viață privată, preocupare de actualitate a UE în domeniul pieței muncii. In: Revista Română de Sociologie. Nr 1-2, București, 2011. [Accesat 21.10.2019]. Disponibil: http://revistadesociologie.ro/en/sites/default/files/07-cleovaridis.pdf

17. PILAR CASAL, M., BARHAM, B. Motherhood wage penalties and labour market segmentation: 
Evidence from Argentina. 2013, december. [Accesat 18.10.2019]. Accesat 18.10.2019].Disponibil: http.ist.psu.edu > viewdoc > download

18. PLATON, C. ș.a. Percepții privind angajamentul de rol și conflictul muncă-familie la angajații din Republica Moldova: studiu explorativ. In: Studia Universitatis Moldaviae. Seria Științe ale Educației. 2016, nr. 9, pp. 148-160. ISSN 1857-2103.

19. SAVINSKAÂ, O. Rabota i sem'â v žizni ženŝin s det'mi-doškol'nikami: opyt goroda. Moskva, 2008.192 s.

20. ST-AMOUR, N. et al. The difficulty of balancing work and family life: impact of the phisical and mental health of Quebec families. 2007, march. [Accesat 15.10.2019]. Disponibil: http://www.ncchpp.ca/docs/633-diffbalancingworkfamilylife.pdf

21. SKINNER, N. CHAPMAN, J. Work-life balance and family friendly policies. 2013. [Accesat 21.10.2019]. Disponibil: https://melbourneinstitute.unimelb.edu.au/assets/documents/hildabibliography/other-publications/2014/Skinner_etal_work_life_balance.pdf

22. SON, H.I., ČERNOVA, Ž.V. Mobil'nye ustrojstva kak sposob ustanovleniâ balansa meždu rabotoj i ličnoj žizn'û: oborotnaâ storona. 2018. [Accesat 15.10.2019]. Disponibil: https://monitoringjournal.ru/index.php/monitoring/article/view/551

23. SULEA, C., VÎRGĂ, D., GALBEN, N. Scala Conflict Muncă-Familie: Analiza proprietăţilor psihometrice ale versiunii în limba română. 2012. [Accesat 10.10.2019]. Disponibil: http://www.ohpedu.ro/articole/scala-conflict-munca-familie-analiza-proprietatilor-psihometriceale-versiunii-in-limba-romana-4/

24. YOUNGCOURT, S., HUFFMAN, A. Family-Friendly Policies in the Police: Implications for WorkFamily Conflict. 2005. [Accesat 13.11.2019]. Disponibil: http://www.apcj.org/documents/1_2_policies.pdf

25. ZAHARIA, V., GAVRILOAIEI, S. Flexibilitatea granițelor muncă-familie în context românesc. 2015, noiembrie. [Accesat 13.11.2019]. Disponibil:

https://www.researchgate.net/publication/290447085_Flexibilitatea_granitelor_muncafamilie_in_context_romanesc

\section{ARTICLE HISTORY}

Received 12 November 2019

Accepted 06 December 2019 